\title{
Quantifying ruminal nitrogen metabolism using the omasal sampling technique in cattle-A meta-analysis ${ }^{1}$
}

\author{
G. A. Broderick, ${ }^{*}$ P. Huhtanen, $\dagger^{2}$ S. Ahvenjärvi, $\ddagger$ S. M. Reynal, ${ }^{* 3}$ and K. J. Shingfield $\ddagger$ \\ *Agricultural Research Service, USDA US Dairy Forage Research Center, 1925 Linden Drive West, Madison, WI 53706 \\ †Department of Animal Science, Swedish University of Agricultural Sciences, Umeå, S-90183 Sweden \\ $\ddagger$ Animal Production Research, MTT Agrifood Research Finland, Jokioinen, FI-31600 Finland
}

\section{ABSTRACT}

Mixed model analysis of data from 32 studies (122 diets) was used to evaluate the precision and accuracy of the omasal sampling technique for quantifying ruminal- $\mathrm{N}$ metabolism and to assess the relationships between nonammonia- $\mathrm{N}$ flow at the omasal canal and milk protein yield. Data were derived from experiments in cattle fed North American diets $(\mathrm{n}=36)$ based on alfalfa silage, corn silage, and corn grain and Northern European diets $(\mathrm{n}=86)$ composed of grass silage and barley-based concentrates. In all studies, digesta flow was quantified using a triple-marker approach. Linear regressions were used to predict microbial-N flow to the omasum from intake of dry matter (DM), organic matter $(\mathrm{OM})$, or total digestible nutrients. Efficiency of microbial-N synthesis increased with DM intake and there were trends for increased efficiency with elevated dietary concentrations of crude protein $(\mathrm{CP})$ and rumendegraded protein (RDP) but these effects were small. Regression of omasal rumen-undegraded protein (RUP) flow on CP intake indicated that an average $32 \%$ of dietary CP escaped and $68 \%$ was degraded in the rumen. The slope from regression of observed omasal flows of RUP on flows predicted by the National Research Council (2001) model indicated that NRC predicted greater RUP supply. Measured microbial-N flow was, on average, $26 \%$ greater than that predicted by the NRC model. Zero ruminal N-balance (omasal $\mathrm{CP}$ flow $=\mathrm{CP}$ intake) was obtained at dietary $\mathrm{CP}$ and RDP concentrations of 147 and $106 \mathrm{~g} / \mathrm{kg}$ of DM, corresponding to ruminal ammonia- $\mathrm{N}$ and milk urea $\mathrm{N}$ concentrations of 7.1 and $8.3 \mathrm{mg} / 100 \mathrm{~mL}$, respectively. Milk protein yield was positively related to the efficiency of microbial-N synthesis and measured RUP concentration. Improved

\footnotetext{
Received December 11, 2009.

Accepted March 19, 2010.

${ }^{1}$ Mention of any trademark or proprietary product in this paper does not constitute a guarantee or warranty of the product by the USDA or the Agricultural Research Service and does not imply its approval to the exclusion of other products that also may be suitable.

${ }^{2}$ Corresponding author: pekka.huhtanen@njv.slu.se

${ }^{3}$ Deceased June 25, 2007.
}

efficiency of microbial-N synthesis and reduced ruminal CP degradability were positively associated with efficiency of capture of dietary $\mathrm{N}$ as milk N. In conclusion, the results of this study indicate that the omasal sampling technique yields valuable estimates of RDP, RUP, and ruminal microbial protein supply in cattle.

Key words: omasal sampling, microbial protein synthesis, protein degradation, milk protein

\section{INTRODUCTION}

Modern metabolizable protein systems have been developed to improve the accuracy of protein feeding to ruminants and to reduce the effect of milk and meat production on the environment. The NRC (2001) protein model for dairy cattle is based on protein degradation and escape, estimated using in situ methodology, plus microbial protein flow quantified using animals cannulated in the abomasum or proximal duodenum. In situ determinations of protein degradation are flawed because of several inherent problems, including 1) the assumption that proteins, peptides, and amino acids in the soluble fraction are completely degraded, 2) the physical restriction of feeds within the bag from microbial interaction and digestion, and 3) the imprecise quantitation of microbial contamination of the undigested residues (Broderick and Cochran, 2000). Duodenal sampling, utilizing internal markers (e.g., purines) or external markers (e.g., ${ }^{15} \mathrm{~N}$ ), has been the principal method applied for assessing dietary and animal factors influencing microbial protein formation in the rumen (Harmon and Richards, 1997). However, estimates of nutrient flow obtained with duodenal sampling have proven less than reliable (Titgemeyer, 1997). Because milk protein synthesis in dairy cows is dictated largely by metabolizable protein supply (NRC, 2001), variation in omasal NAN flow among dietary treatments should reflect differences in milk protein yield. Precision within study (residual standard deviation) is more important than accuracy when comparing different treatments in nutritional experiments, whereas accurate description of feedstuffs and diets is more important in feed evaluation systems (St-Pierre, 2001). 
Our objective was to evaluate the omasal sampling technique for quantifying the effects of ruminal protein degradation and escape and microbial protein yield on NAN flow and evaluate the relationship between NAN supply and milk protein yield. Furthermore, measurements of NAN flow at the omasum were compared with flows of microbial protein and dietary undegraded protein predicted by the NRC (2001) model. This paper is a companion to a meta-analysis of omasal sampling data on partitioning of NDF and OM digestion between ruminal and postruminal compartments of the gastrointestinal tract (Huhtanen et al., 2010).

\section{MATERIALS AND METHODS}

\section{Data}

Observations were collected from 32 studies in which nutrient flow at the omasum was determined for 122 dietary treatments. Twenty-two of these studies were conducted in Northern Europe: 3 trials (10 diets) were conducted by 1 research group with growing cattle and 19 trials (76 diets) were conducted with lactating dairy cows by 2 other research groups. Ten studies (36 diets) were conducted in North America by 2 additional research groups using only lactating dairy cows; individual studies used to compile this dataset are listed in the Appendix of the companion paper (Huhtanen et al., 2010) for the literature citations comprising this data set. All studies were conducted using changeover designs. The mean number of observations per dietary treatment was 5.3 (range 4-10). In all studies, digesta flow to the omasum was determined using a triple-marker approach (France and Siddons, 1986). The digesta markers were indigestible NDF $(\mathrm{n}=100)$ or Cr-mordanted fiber $(\mathrm{n}=22)$ for the large particle phase, Yb-chloride or Yb-acetate for small particle phase, and CoEDTA for the liquid phase. When used, Cr-mordanted fiber was administered twice daily into the rumen. Both Yb-chloride/acetate and CoEDTA were continuously administered into the rumen. Microbial protein synthesis was determined for 96 diets (25 studies) using purine bases (22 diets) or ${ }^{15} \mathrm{~N}$ (74 diets) as microbial markers. Efficiency of microbial protein synthesis was calculated per kilogram of OM truly digested in the rumen (OMTDR). In the North American studies, OMTDR values did not account for VFA flow to the omasum. As a result, values reported for OMTDR were underestimates of true OM digestion in the rumen because VFA are not lost during drying at typical omasal digesta $\mathrm{pH}$ (mean 6.5). Therefore, reported OMTDR values were corrected for VFA flow using a relationship between DMI and VFA flow derived from the other studies as described in the companion paper (Huhtanen et al., 2010). Total-tract digestibility and fermentation pattern were determined in all studies as described in the companion paper (Huhtanen et al., 2010). Milk urea N concentration was determined for 94 diets using ammonia release following urease hydrolysis (McCullough, 1967) or an automated colorimetric assay (Broderick and Clayton, 1997).

\section{Diets and Calculations}

The diets were typical of those fed to dairy and beef cattle in North America $(\mathrm{n}=36)$ and Northern Europe $(\mathrm{n}=86)$. The analyses used to determine dietary composition are detailed in the companion paper (Huhtanen et al., 2010) and the original publications. Predicted intakes, concentrations of RDP, RUP, and microbial CP, total CP flows (microbial CP + RUP), and dietary concentrations of NFC and total digestible $\mathrm{OM}$ at $1 \times$ maintenance intake (DOM; $\mathrm{g} / \mathrm{kg}$ of DM) were also estimated as described in the companion paper (Huhtanen et al., 2010).

Total digestible nutrients $(\mathbf{T D N})$ at $1 \times$ maintenance level of intake $\left(\mathbf{T D N}_{\mathbf{M}} ; \mathrm{g} / \mathrm{kg}\right.$ of $\left.\mathrm{DM}\right)$ were calculated from DOM (NRC, 2001): $\mathrm{TDN}_{\mathrm{M}}=\mathrm{DOM}+1.25 \times$ fatty acids $(\mathrm{g} / \mathrm{kg}$ of $\mathrm{DM})$ to account for the greater energy content of lipid compared with the other chemical components. Concentrations of TDN at observed levels of production $\left(\mathrm{TDN}_{\mathrm{P}}\right)$ were calculated according to $\mathrm{NRC}$ (2001) using the following equation to discount for decreases in digestibility with increased intake: $\mathrm{TDN}_{\mathrm{P}}=$ $\left.\mathrm{TDN}_{\mathrm{M}}-\left[0.18 \times \mathrm{TDN}_{\mathrm{M}}-103\right) \times(\mathrm{FL}-1)\right]$, where FL $=$ feeding level as a multiple of maintenance. Feeding level for the Northern European data set was calculated using energy requirements of $0.123 \mathrm{Mcal}$ of $\mathrm{ME} / \mathrm{kg}$ of $\mathrm{BW}^{0.75}$ and $1.23 \mathrm{Mcal} / \mathrm{kg}$ of ECM for maintenance and milk production, respectively (MTT, 2006).

Concentrations of RDP and RUP were calculated using tabulated values (NRC, 2001) for CP degradation parameters. For grass silages, parameter values tabulated by NRC (2001) were selected based on the closest NDF concentration. The NRC (2001) does not assign specific protein degradation parameters for red clover silage; therefore, degradation parameters reported for legume silages were also applied to red clover silage. Effective protein degradability was calculated using passage rates estimated from the data set using NRC (2001) equations.

Feed N flow was computed as total NAN flow - microbial N flow; thus, our estimates of feed RUP generally included protein of endogenous origin. Feed $\mathrm{N}$ flow was also calculated using the following corrections for underestimation of microbial $\mathrm{N}$ flow and endogenous $\mathrm{N}$ contribution to omasal NAN flow. In most studies, microbial $\mathrm{N}$ flow was determined using ${ }^{15} \mathrm{~N}$ as the refer- 
ence marker. Because isolated microbial samples did not include protozoa, which have lower ${ }^{15} \mathrm{~N}$ enrichment than bacteria (Hristov and Broderick, 1996; Ahvenjärvi et al., 2002), microbial N flow will be underestimated, depending on the contribution of protozoa to microbial $\mathrm{N}$ flow. Assuming that ${ }^{15} \mathrm{~N}$ enrichment of protozoa is, on average, $50 \%$ of that in bacteria (Hristov and Broderick, 1996; Ahvenjärvi et al., 2002) and that protozoa contribute $10 \%$ to microbial $\mathrm{N}$ flow (Ahvenjärvi et al., 2002), the ${ }^{15} \mathrm{~N}$ method would underestimate microbial $\mathrm{N}$ flow by about $5 \%$. Endogenous $\mathrm{N}$ flow into the omasum was estimated assuming NAN flow of either $0.085 \mathrm{~g} /$ $\mathrm{kg}$ of $\mathrm{BW}^{0.75}$ (Ørskov et al., 1986) or $2 \mathrm{~g} / \mathrm{kg}$ of DMI (Hart and Leibholz, 1990). The former is derived using intragastric infusion of protein-free nutrients and the latter by determining omasal NAN flow on a RUP-free diet using ${ }^{15} \mathrm{~N}$ as microbial marker.

Ruminal CP $(\mathrm{N})$ balance (g of $\mathrm{CP} / \mathrm{kg}$ of $\mathrm{DMI}$ ) was calculated as [CP intake $(\mathrm{g} / \mathrm{d})-6.25 \times$ omasal NAN flow $(\mathrm{g} / \mathrm{d})] / \mathrm{DMI}(\mathrm{kg} / \mathrm{d})$. Positive values indicate net $\mathrm{N}$ loss from the rumen and negative values indicate net utilization of recycled $\mathrm{N}$.

\section{Statistical Analysis}

Data were analyzed using mixed model procedures of SAS (Littell et al., 1996). The model was $\mathrm{Y}=\mathrm{B}_{0}$ $+\mathrm{B}_{1} \mathrm{X} 1_{\mathrm{ij}}+\mathrm{b}_{0}+\mathrm{b}_{1} \mathrm{X} 1_{\mathrm{ij}}+\mathrm{B}_{2} \mathrm{X} 2_{\mathrm{ij}}+\ldots+\mathrm{B}_{\mathrm{n}} \mathrm{Xn} n_{\mathrm{ij}}+\mathrm{e}_{\mathrm{ij}}$, where $\mathrm{B}_{0}, \mathrm{~B}_{1} \mathrm{X} 1_{\mathrm{ij}}, \mathrm{B}_{2} \mathrm{X} 2_{\mathrm{ij}} \ldots \mathrm{B}_{\mathrm{n}} \mathrm{Xn}_{\mathrm{ij}}$ were the fixed effects and $b_{0}, b_{1}$ and $e_{i j}$ were the random experimental effects (intercept and slope), $\mathrm{i}=1 \ldots \mathrm{n}$ studies and $\mathrm{j}=1 \ldots$ $\mathrm{n}_{\mathrm{i}}$ values. Because some models did not converge when the slope was random, only random intercepts for all models that predicted the same dependent variable were used. The models were first constructed based on a single parameter and then other biologically relevant variables were included incrementally. Any additional parameter was assumed to be a fixed factor. The best fitting models were chosen based on 1) the lowest residual mean-square error (RMSE), and then on 2) Akaike's information criterion (Littell et al., 1996). In Tables 2-6, RMSE values were adjusted for the random effect of study. The rationale and further details of using mixed model analysis to integrate quantitative findings from multiple studies are described by St-Pierre (2001). Estimates of N flow made using the NRC (2001) model were evaluated by regressing residuals (observed using omasal sampling - predicted using the NRC model) on values predicted using the NRC model (St-Pierre, 2003). Predicted values were centered by subtracting the mean of all predicted values from individual predictions. This made the slope and intercept estimates in the regression orthogonal and, thus, independent. Mean biases were assessed using the intercepts of the regres- sion equations. The slopes of the regression equations were used to determine the presence of linear biases.

\section{RESULTS}

\section{Data}

A description of the data used in these analyses is in Table 1. Both the animal and feed data covered ranges encompassing most typical dairy cow diets. Lowest intakes were found in studies with growing cattle, with the minimum DMI in dairy cattle being $13.8 \mathrm{~kg} / \mathrm{d}$.

\section{Microbial Protein Synthesis}

Regression equations predicting microbial $\mathrm{N}$ flow as functions of intake and concentration of various dietary components are in Table 2. Differences among the intake parameters used to predict microbial $\mathrm{N}$ flow were small and microbial $\mathrm{N}$ flow to the omasum was reliably predicted $(P<0.001)$, regardless of whether intake was expressed as DM, OM, TDN, OMTDR, or OMTDR discounted for fat and RUP. No trend $(P=0.37)$ was found for a quadratic relationship between OMTDR intake and microbial $\mathrm{N}$ flow. Regressions based on intake of DM, OM, or TDN (not shown) also did not exhibit any quadratic trends. Except for dietary CP content $(P=0.04)$, concentration of chemical components in the diet, including carbohydrates (NDF, NFC) and fat, did not improve predictions of microbial $\mathrm{N}$ flow. The relationship between $\mathrm{OM}$ intake and microbial $\mathrm{N}$ flow, estimated by a simple regression analysis without study effect, is presented in Figure 1. The intercept of the linear model was significantly negative $(P<0.001)$, whereas it was not different from zero $(P=0.80)$ with the quadratic model. This suggested that microbial efficiency would be lower at reduced feed intakes. Moreover, although both the linear and quadratic regressions fit the data equally well, extrapolating the linear equation to OM intakes below the lower limit of the data would yield erroneous estimates of microbial $\mathrm{N}$ flow.

Efficiency of microbial $\mathrm{N}$ synthesis ( $\mathrm{g}$ of microbial $\mathrm{N} / \mathrm{kg}$ of OMTDR $)$ improved $(P<0.01)$ with increased DMI (Figure 2). The quadratic effect tended $(P=0.07)$ to be significant, which suggested diminishing increases in microbial $\mathrm{N}$ efficiency with increased DMI, but model fit was not improved as assessed by Akaike's information criterion or adjusted RMSE (Table 2). Microbial efficiency also tended to increase with elevated dietary concentrations of $\mathrm{CP}(P=0.10)$ and $\operatorname{RDP}(P=0.12)$, but these effects were numerically small (about $0.02 \mathrm{~g}$ of $\mathrm{N} / \mathrm{kg}$ of OMTDR per $\mathrm{kg}$ increase in DMI). Dietary concentrations of NDF, NFC or fat had no effect on the efficiency of microbial $\mathrm{N}$ synthesis when included as 
Table 1. Statistical description of variables used in the data set for the prediction of the flow of $\mathrm{N}$ fractions into the omasum

\begin{tabular}{|c|c|c|c|c|c|c|}
\hline Item & Unit & $\mathrm{n}$ & Mean & $\mathrm{SD}$ & Minimum & Maximum \\
\hline $\mathrm{DM}$ & $\mathrm{kg} / \mathrm{d}$ & 122 & 19.1 & 4.42 & 6.0 & 27.4 \\
\hline $\mathrm{OM}$ & $\mathrm{kg} / \mathrm{d}$ & 122 & 17.7 & 4.15 & 5.5 & 25.3 \\
\hline $\mathrm{TDN}^{2}$ & $\mathrm{~kg} / \mathrm{d}$ & 122 & 12.6 & 2.75 & 3.8 & 17.5 \\
\hline Nitrogen & $\mathrm{g} / \mathrm{d}$ & 122 & 493 & 149 & 104 & 745 \\
\hline RDP & $\mathrm{g} / \mathrm{d}$ & 122 & 2,177 & 628 & 500 & 3,382 \\
\hline NFC & $\mathrm{kg} / \mathrm{d}$ & 122 & 7.1 & 2.91 & 1.1 & 13.4 \\
\hline \multicolumn{7}{|l|}{ Concentration } \\
\hline $\mathrm{CP}$ & $\mathrm{g} / \mathrm{kg}$ of $\mathrm{DM}$ & 122 & 159 & 22.6 & 99 & 237 \\
\hline RDP & $\mathrm{g} / \mathrm{kg}$ of $\mathrm{DM}$ & 122 & 113 & 17.3 & 75 & 177 \\
\hline RUP & $\mathrm{g} / \mathrm{kg}$ of $\mathrm{DM}$ & 122 & 46 & 12.5 & 23 & 98 \\
\hline NDF & $\mathrm{g} / \mathrm{kg}$ of $\mathrm{DM}$ & 122 & 372 & 83.7 & 219 & 595 \\
\hline NFC & $\mathrm{g} / \mathrm{kg}$ of $\mathrm{DM}$ & 122 & 363 & 86.3 & 147 & 554 \\
\hline \multicolumn{7}{|l|}{ Omasal flow } \\
\hline $\mathrm{OM}$ & $\mathrm{kg} / \mathrm{d}$ & 122 & 9.4 & 2.57 & 2.6 & 14.5 \\
\hline NAN & $\mathrm{g} / \mathrm{d}$ & 122 & 472 & 144.6 & 87 & 767 \\
\hline Microbial N & $\mathrm{g} / \mathrm{d}$ & 96 & 322 & 109.1 & 78 & 480 \\
\hline Feed N & $\mathrm{g} / \mathrm{d}$ & 96 & 166 & 58.3 & 7 & 315 \\
\hline Microbial efficiency & $\mathrm{g}$ of $\mathrm{N} / \mathrm{kg}$ of OMTDR & 96 & 23.7 & 3.91 & 13.5 & 30.8 \\
\hline
\end{tabular}

${ }^{1} \mathrm{OMTDR}=\mathrm{OM}$ truly digested in the rumen.

${ }^{2}$ Total digestible nutrients (TDN) discounted for feeding level effects according to NRC (2001).

the second or third variable in models along with DMI, CP concentration, or both. The relationship between microbial efficiency and DMI also was significant $(P<$ 0.001) when estimated using a simple regression model, but the magnitude of the effect was greater $(0.53 \mathrm{~g}$ per $\mathrm{kg}$ increase in DMI).

\section{Feed Protein Flow and RUP Concentration}

Regression models predicting omasal RUP flow, and concentration of RDP and RUP [(NAN flow - microbial $\mathrm{N}) \times 6.25]$ in omasal digesta, from intake or dietary concentration of different protein fractions are in Table 3. These estimates were not corrected for endogenous NAN. The slope from regressing omasal RUP flow on CP intake was 0.32 , suggesting that on average $68 \%$ of feed protein was degraded in the rumen. The slope between RUP intake, predicted with the NRC (2001) model, and observed omasal RUP flow was 0.78 and was different $(P<0.001)$ from 1 . The effect of RDP intake also was significant $(P=0.03)$, indicating that a fraction of the CP defined as RDP by NRC (2001) escaped ruminal degradation as measured by omasal sampling. The slope (0.80) between the NRC (2001) predicted and observed RDP concentration also was different $(P<0.001)$ from 1 and the models suggested that 7 to $9 \%$ of predicted RDP escaped the rumen as undegraded protein. On the other hand, $25 \%$ of predicted RUP was recovered as RDP when the prediction was based on either a single (RUP) or bivariate (RDP and RUP) mixed regression model (Table 3). It is worth noting that the correlation coefficient between dietary concentrations of RDP and RUP was small $(0.13)$ and nonsignificant $(P=0.21)$. The relationships between independent variables and observed dietary RUP concentrations were similar to those observed for RUP flow.

\section{NRC (2001) Predictions of Ruminal Flows of Microbial and Feed Protein}

The slope between ruminal outflow of protein-N [(RUP + microbial protein)/6.25], predicted by NRC (2001), and total NAN flow measured by omasal sampling was 1.06 when estimated with a mixed model regression when endogenous $\mathrm{N}(1.9 \times \mathrm{DMI})$ was included as part of NRC (2001) NAN flow (Figure 3). This slope was not different from $1(P=0.16)$ but the slope increased to 1.12 , a value greater than $1(P=0.01)$, when the endogenous $\mathrm{N}$ estimated by the NRC model was excluded from predicted NAN. The RMSE was $44.1 \mathrm{~g} / \mathrm{d}$ for the simple regression model.

There was a slope bias of 0.26 in microbial CP flow $(P$ $=0.01$, Figure 4$)$, indicating that measured microbial $\mathrm{CP}$ flow was 1.26 times greater than that predicted by 
Table 2. Regressions developed for predicting microbial $\mathrm{N}$ flow at the omasum from various intake and dietary parameters ${ }^{1}$

\begin{tabular}{|c|c|c|c|c|c|c|c|c|c|c|c|c|c|c|c|c|}
\hline $\mathrm{X}_{1}$ & $\mathrm{X}_{2}$ & $\mathrm{X}_{3}$ & Intercept & $\mathrm{SE}$ & $P$-value & Slope $_{1}$ & $\mathrm{SE}$ & $P$-value & Slope $_{2}$ & $\mathrm{SE}$ & $P$-value & Slope $_{3}$ & $\mathrm{SE}$ & $P$-value & $\mathrm{RMSE}^{2}$ & $\mathrm{AIC}^{3}$ \\
\hline \multicolumn{17}{|c|}{$\mathrm{Y}=$ microbial $\mathrm{N}$ flow $(\mathrm{g} / \mathrm{d})$} \\
\hline DM & & & -61 & 26.8 & 0.03 & 19.6 & 1.33 & $<0.001$ & & & & & & & 16.84 & 902.3 \\
\hline $\mathrm{OM}$ & & & -57 & 26 & 0.04 & 20.9 & 1.39 & $<0.001$ & & & & & & & 16.53 & 899.3 \\
\hline OMTDR & & & -31 & 26.1 & 0.25 & 26.7 & 1.91 & $<0.001$ & & & & & & & 17.65 & 909.6 \\
\hline cOMTDR & & & 0 & 29.6 & 0.99 & 27.4 & 2.42 & $<0.001$ & & & & & & & 18.25 & 924.3 \\
\hline TDN & & & -35 & 28.2 & 0.22 & 28.0 & 2.14 & $<0.001$ & & & & & & & 17.07 & 909.9 \\
\hline OMTDR & $\mathrm{CP}$ & & -75 & 31.6 & 0.03 & 25.9 & 1.90 & $<0.001$ & 0.33 & 0.16 & 0.04 & & & & 17.56 & 907.1 \\
\hline OMTDR & RDP & & -61 & 31.6 & 0.07 & 26.2 & 1.91 & $<0.001$ & 0.32 & 0.19 & 0.11 & & & & 17.49 & 908.4 \\
\hline OMTDR & RUP & & -44 & 26.5 & 0.11 & 26.4 & 1.91 & $<0.001$ & 0.36 & 0.28 & 0.20 & & & & 17.84 & 908.7 \\
\hline OMTDR & NDF & & -18 & 52.7 & 0.74 & 26.3 & 2.34 & $<0.001$ & -0.021 & 0.077 & 0.79 & & & & 17.70 & 912.8 \\
\hline OMTDR & NFC & & -27 & 28.1 & 0.35 & 27.2 & 2.13 & $<0.001$ & -0.03 & 0.062 & 0.63 & & & & 17.78 & 913.1 \\
\hline OMTDR & Fat & & -51 & 29.9 & 0.10 & 26.0 & 2.06 & $<0.001$ & 1.04 & 0.98 & 0.29 & & & & 17.92 & 906.8 \\
\hline OMTDR & $\mathrm{CP}$ & $\mathrm{NDF}$ & -64 & 55.2 & 0.26 & 25.6 & 2.32 & $<0.001$ & 0.33 & 0.16 & 0.04 & -0.016 & 0.075 & 0.83 & 17.63 & 910.4 \\
\hline OMTDR & $\mathrm{CP}$ & NFC & -82 & 37.9 & 0.04 & 25.4 & 2.28 & $<0.001$ & 0.36 & 0.18 & 0.04 & 0.028 & 0.067 & 0.68 & 17.60 & 910.5 \\
\hline OMTDR & $\mathrm{CP}$ & Fat & -93 & 34.1 & 0.01 & 25.3 & 2.05 & $<0.001$ & 0.33 & 0.16 & 0.04 & 1.01 & 0.96 & 0.30 & 17.86 & 904.4 \\
\hline \multicolumn{17}{|c|}{$\begin{array}{l}\mathrm{Y}=\text { microbial efficiency } \\
(\mathrm{g} \text { of } \mathrm{N} / \mathrm{kg} \text { of OMTDR) }\end{array}$} \\
\hline $\mathrm{DM}$ & & & 15.1 & 2.01 & $<0.001$ & 0.44 & 0.100 & $<0.001$ & & & & & & & 1.42 & 429.3 \\
\hline DM & $\mathrm{DM}^{2}$ & & 8.7 & 4.12 & 0.04 & 1.27 & 0.467 & 0.01 & -0.024 & 0.0132 & 0.07 & & & & 1.39 & 432.9 \\
\hline OMTDR & & & 18.2 & 2.06 & $<0.001$ & 0.42 & 0.151 & 0.01 & & & & & & & 1.45 & 436.9 \\
\hline OMTDR & OMTDR $^{2}$ & & 10.6 & 4.71 & 0.03 & 1.77 & 0.774 & 0.03 & -0.0552 & 0.0312 & 0.08 & & & & 1.44 & 438.9 \\
\hline $\mathrm{DM}$ & $\mathrm{CP}$ & & 12.7 & 2.39 & $<0.001$ & 0.4 & 0.102 & $<0.001$ & 0.0208 & 0.0127 & 0.10 & & & & 1.43 & 433.6 \\
\hline DM & RDP & & 13 & 2.44 & $<0.001$ & 0.43 & 0.100 & $<0.001$ & 0.0214 & 0.0152 & 0.16 & & & & 1.42 & 433.8 \\
\hline $\mathrm{DM}$ & NDF & & 12.7 & 3.96 & 0.004 & 0.49 & 0.121 & $<0.001$ & 0.0039 & 0.0057 & 0.50 & & & & 1.44 & 437.3 \\
\hline $\mathrm{DM}$ & NFC & & 15.8 & 2.13 & $<0.001$ & 0.49 & 0.107 & $<0.001$ & -0.0046 & 0.0046 & 0.32 & & & & 1.44 & 437.3 \\
\hline DM & Fat & & 15.4 & 2.26 & $<0.001$ & 0.46 & 0.119 & $<0.001$ & -0.0187 & 0.0799 & 0.82 & & & & 1.42 & 432.4 \\
\hline
\end{tabular}

${ }^{1}$ Intake parameters expressed as kg/d were DM, OM, OMTDR (OM truly digested in the rumen), cOMTDR (OM truly digested in the rumen, corrected for fat and RUP), and total digestible nutrients (TDN); dietary concentrations expressed as $\mathrm{g} / \mathrm{kg}$ of DM were CP, RDP, RUP, NDF, NFC, and fat.

${ }^{2}$ Residual mean square error; adjusted for the random study effect.

${ }^{3}$ Akaike's information criteria. 


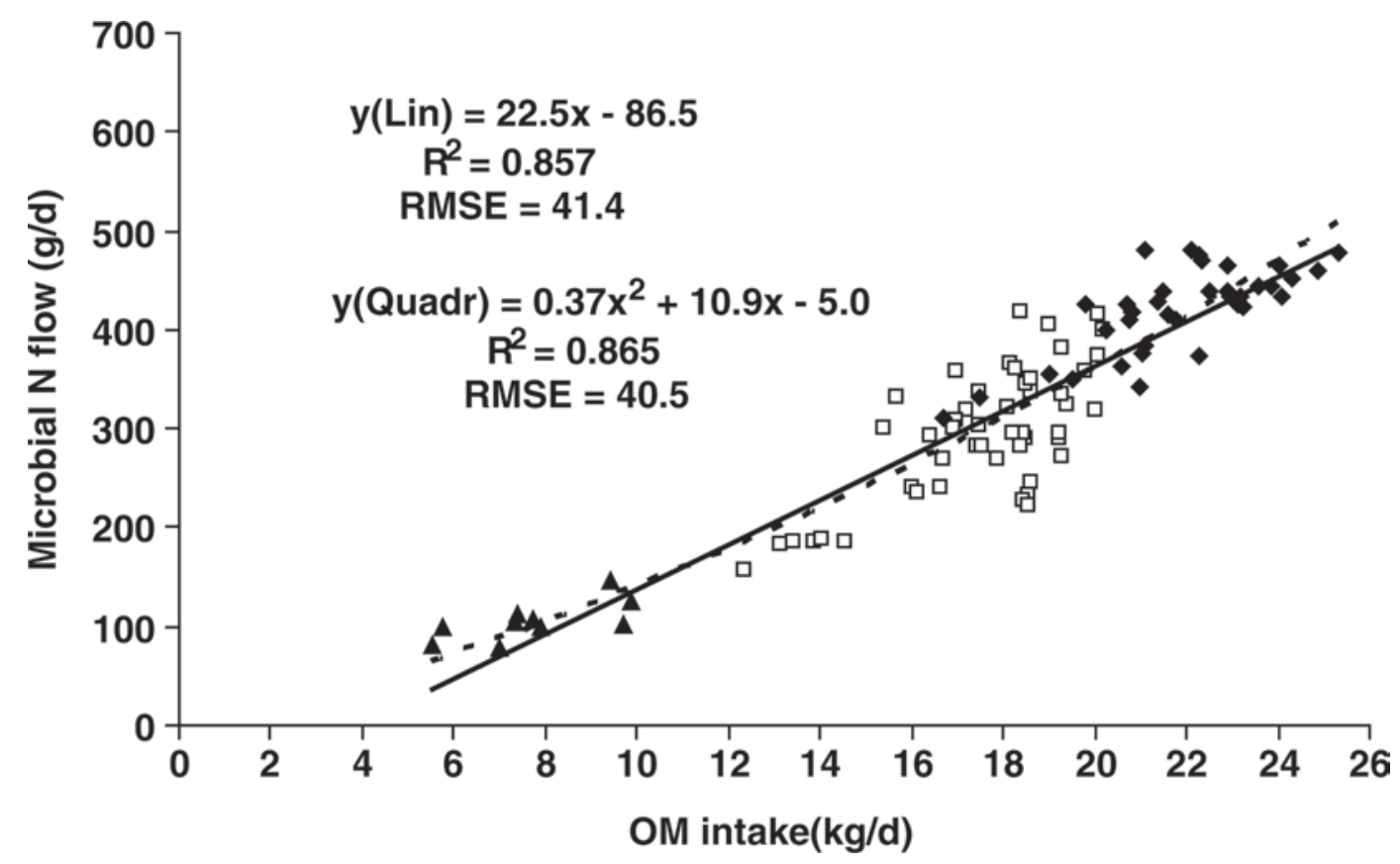

Figure 1. The relationships between $\mathrm{OM}$ intake and microbial $\mathrm{N}$ flow into the omasum $(\mathrm{n}=96)$ estimated using simple linear (Lin) or quadratic (Quadr) regression models. $\Delta$ European beef cattle trials; $\square$ European dairy cow trials; $\bullet$ North American dairy cow trials. RMSE $=$ residual mean-square error.

the NRC (2001) model. However, unlike microbial N, the slope between predicted and observed feed RUP flow was 0.78 (Figure 5), which was significantly less than 1 $(P=0.001)$. As in the previous comparison, predicted RUP flow did not include CP derived from endogenous
N, whereas observed RUP flow was not corrected for the contribution from endogenous CP. Greater flows of microbial NAN were also reported from earlier research in which omasal sampling was compared directly to duodenal sampling in the same trial, but differences

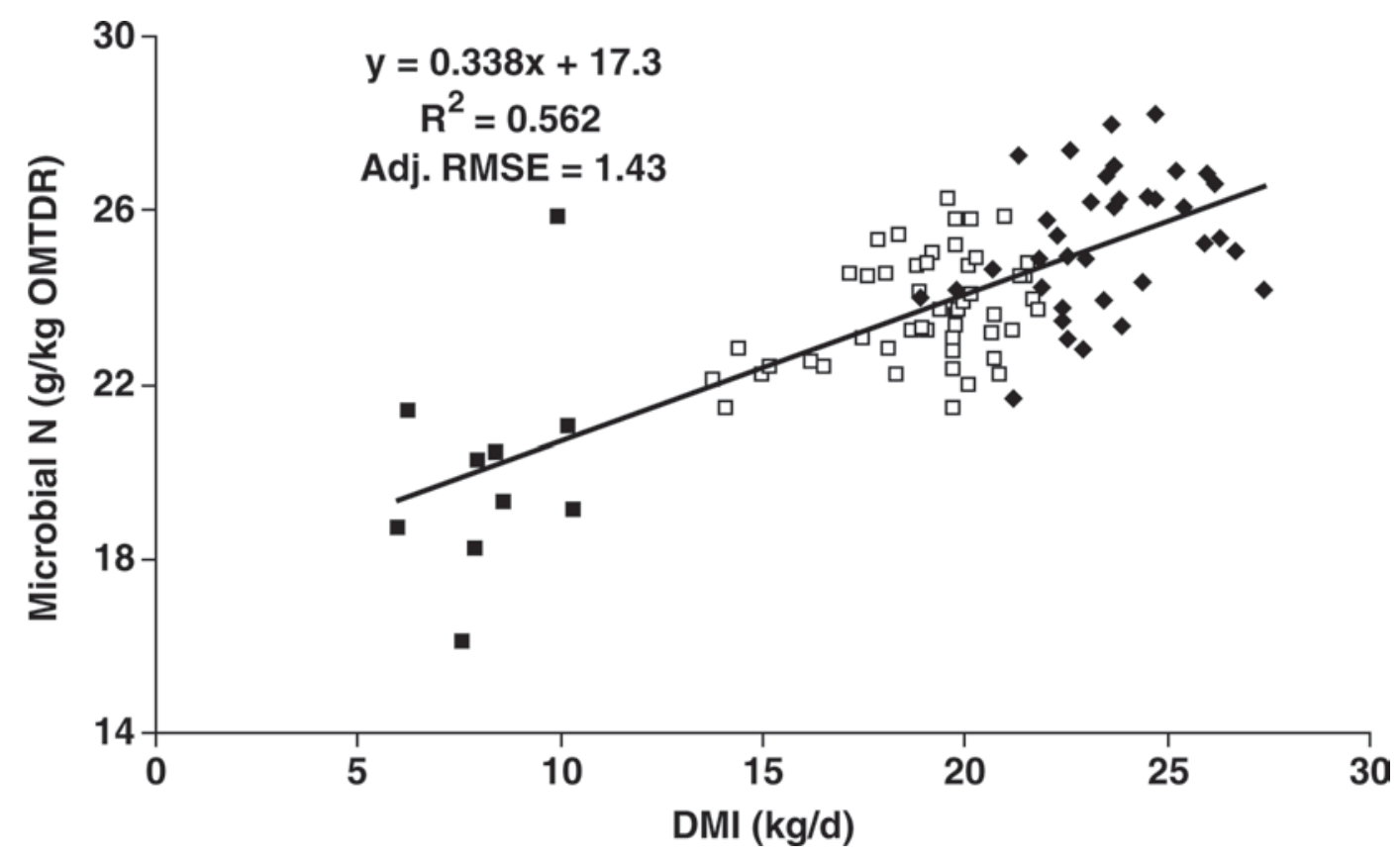

Figure 2. The relationship between DMI and the efficiency of microbial N synthesis in the rumen $(\mathrm{n}=96)$ estimated using a mixed regression model. European beef cattle trials; $\square$ European dairy cow trials; $\bullet$ North American dairy cow trials. RMSE $=$ residual mean-square error; $\mathrm{OMTDR}=\mathrm{OM}$ truly digested in the rumen. 
were of smaller magnitude. In contrast to sampling at the duodenum, Ahvenjärvi et al. (2000) observed $5 \%$ greater and Ipharraguerre et al. (2007) found 10\% greater microbial flow with omasal sampling when total purines were used as the bacterial marker.

The residuals (observed using omasal sampling - predicted using the NRC model) for flows of total NAN, microbial $\mathrm{N}$, and feed $\mathrm{N}$ were plotted against values predicted by the NRC (2001) model in Figure 6. Again, predicted NAN flow included the contribution of endogenous $\mathrm{N}(1.9 \mathrm{~g} / \mathrm{kg}$ of DMI) and omasal feed $\mathrm{N}$ flow was not discounted for endogenous N. The NRC (2001) model yielded estimates of total NAN and microbial $\mathrm{N}$ flow that were higher $(P<0.001)$ by 7 and $22 \%$, respectively, and gave positive $(P<0.001)$ linear biases of 0.063 and 0.260 . However, there was also a linear bias $(P<0.001)$ of -0.224 for feed $\mathrm{N}$ flow. Adjusting for protozoal $\mathrm{N}$ had little effect on mean bias. However, bias for feed $\mathrm{N}$ flow was strongly influenced by the assumptions made regarding endogenous $\mathrm{N}$ flow (which was not measured): mean bias was reduced from 11.0 $\mathrm{g} / \mathrm{d}$ to zero, using the endogenous $\mathrm{N}$ flow estimated according to Ørskov et al. (1986) and to $-44.6 \mathrm{~g} / \mathrm{d}$, using the endogenous $\mathrm{N}$ flow estimated according to Hart and Leibholz (1990) (Table 4).

\section{Ruminal N-Balance}

Regression models predicting ruminal N-balance [(N intake - omasal NAN flow)/DMI] are in Table 5. All regressions were derived from data sets that also included MUN concentrations $(\mathrm{n}=96)$. Ruminal N-balance became more positive as dietary CP and RDP concentration increased. Regressions that included data on measured ruminal protein degradability fit better than those based on dietary $\mathrm{CP}$ alone. Including the dietary concentration of RUP tended to increase $(P=0.07)$ ruminal N-balance when included in the model along with dietary RDP concentration. Ruminal ammonia-N concentration was the best predictor of ruminal N-balance. Zero ruminal N-balance (where omasal $\mathrm{CP}$ flow $=\mathrm{CP}$ intake) was estimated to occur at dietary $\mathrm{CP}$ and $\mathrm{RDP}$ concentrations of 147 and $106 \mathrm{~g} / \mathrm{kg}$ of DM, where mean ruminal ammonia-N and MUN concentrations were 7.1 and $8.3 \mathrm{mg} / 100 \mathrm{~mL}$, respectively, suggesting that MUN could serve as an indirect indicator of ruminal $\mathrm{N}$ status.

\section{Milk Protein Yield and N Efficiency}

Regression equations developed to estimate milk protein yield (MPY) and milk N efficiency (MNE; Milk $\mathrm{N} / \mathrm{N}$ intake) from several independent variables in the omasal sampling data set are in Table 6. Milk protein

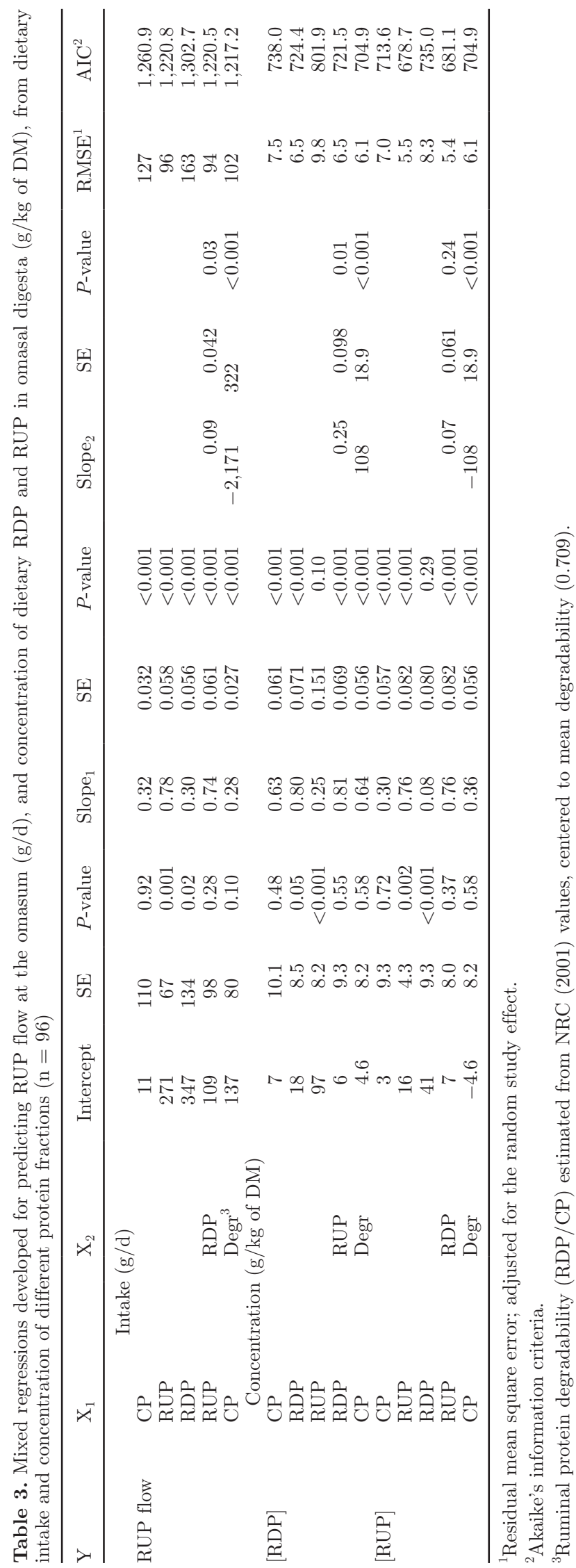




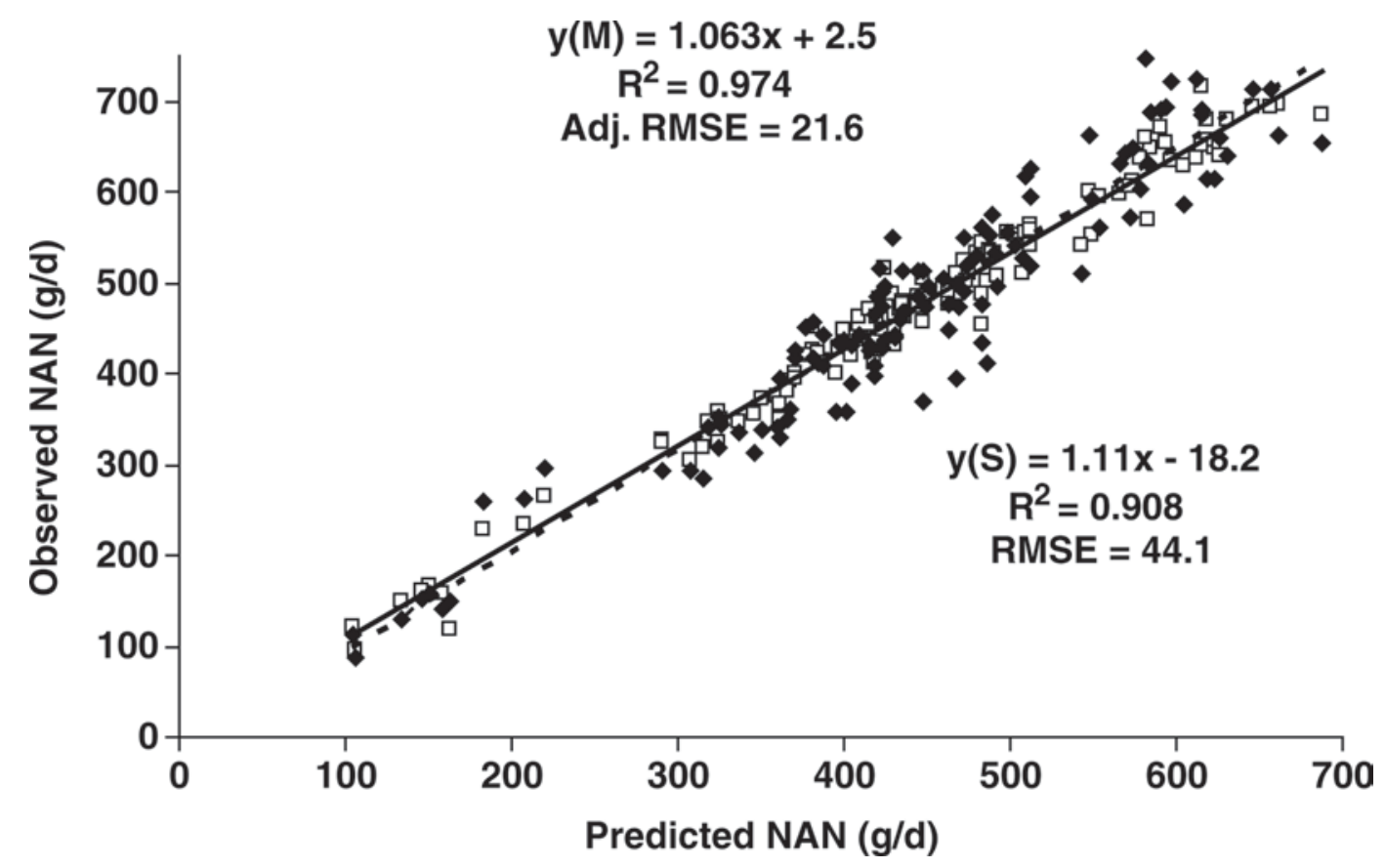

Figure 3. The relationship between predicted (NRC, 2001) and observed NAN flows into the omasum (n = 122) estimated using either a mixed ( $\mathrm{M}$; open symbols) or simple (S; closed symbols) regression model. RMSE $=$ residual mean-square error.

yield was positively related to efficiency of microbial $\mathrm{N}$ synthesis and dietary RUP concentration. Parameter values were similar for the mixed and simple regression models without study effect. Small RMSE and high $\mathrm{R}^{2}$ values suggested that these regression models accurately predicted MPY. With the MPY models, improved efficiency of microbial $\mathrm{N}$ synthesis and reduced ruminal protein degradability were positively associated with

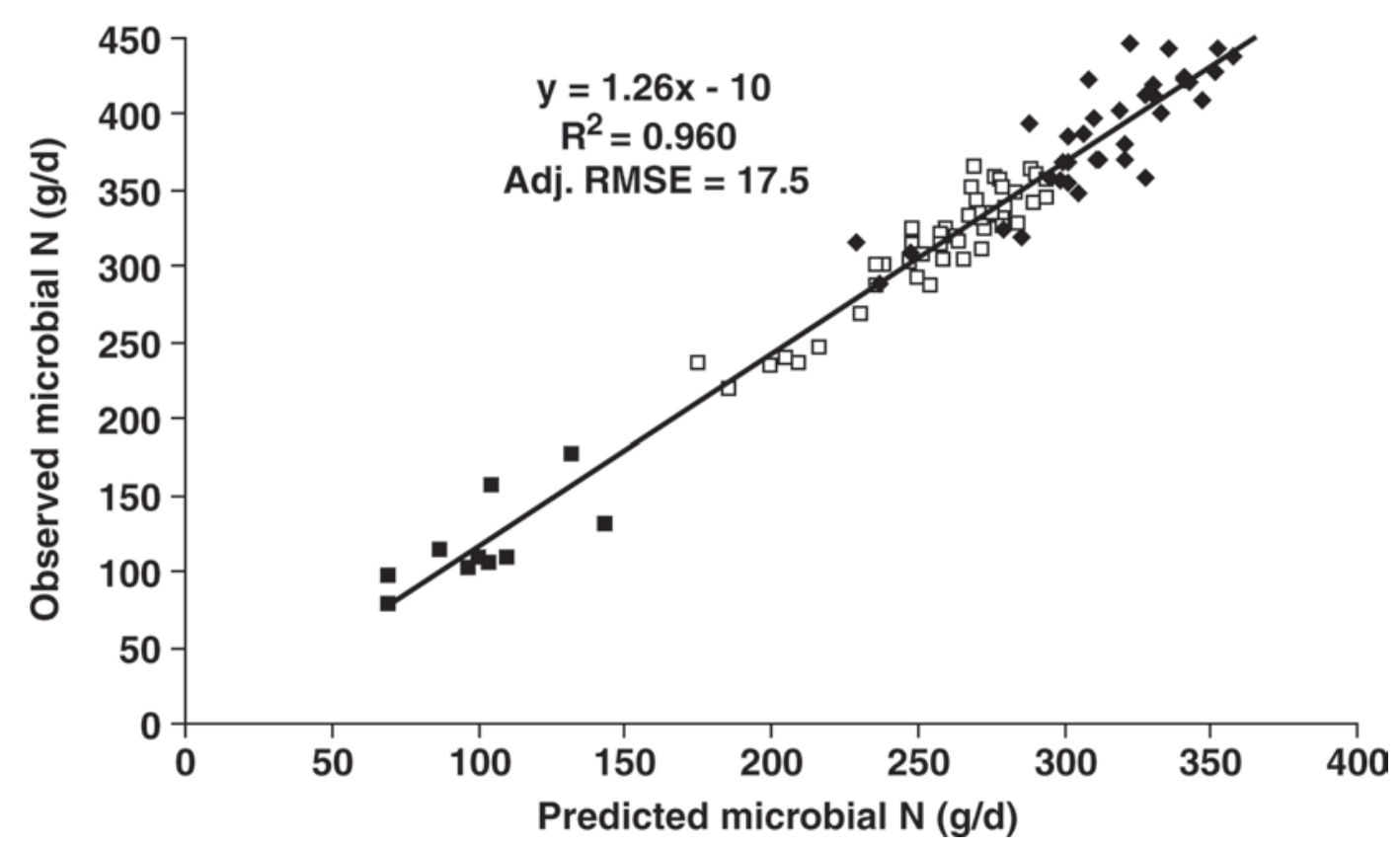

Figure 4. The relationship between predicted (NRC, 2001) and observed microbial N flows into the omasum (n = 96) estimated using a mixed regression model. $\square$ European beef cattle trials; $\square$ European dairy cow trials; $\bullet$ North American dairy cow trials. RMSE $=$ residual mean-square error. 


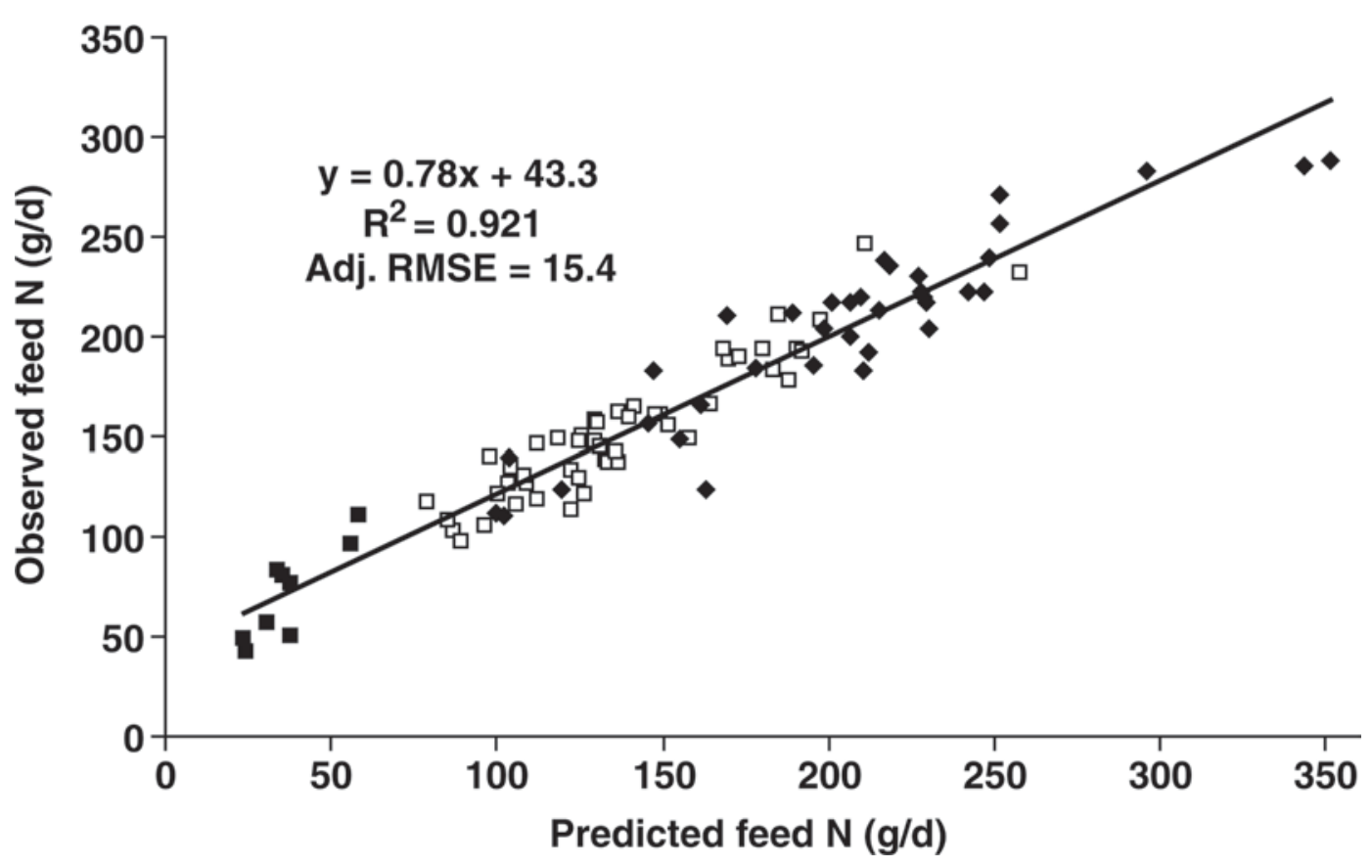

Figure 5. The relationship between predicted (NRC, 2001) and observed feed $\mathrm{N}$ flows (NAN flow - microbial $\mathrm{N}$ flow) into the omasum $(\mathrm{n}=$ 96) estimated using a mixed regression model. $\square$ European beef cattle trials; $\square$ European dairy cow trials; $\bullet$ North American dairy cow trials. RMSE $=$ residual mean-square error.

MNE when included in the model with dietary CP concentration. The effect of protein degradability on MNE only tended $(P=0.11)$ to be significant.

\section{DISCUSSION}

The omasal sampling technique offers several advantages for studying ruminal-N metabolism compared with abomasal or duodenal sampling. First, the method is less invasive because only ruminal cannulas are required (Huhtanen et al., 1997; Ahvenjärvi et al., 2000); second, the contribution from endogenous $\mathrm{N}$ secretion is reduced compared with duodenal sampling (Ørskov et al., 1986; Hart and Leibholz, 1990); and third, sam- pling before the start of enzymatic hydrolysis in the abomasum allows more detailed investigations of the flow of soluble NAN components from the rumen (Choi et al., 2002; Reynal et al., 2007). Because most of the cell wall digestion in cattle takes place in the rumen (Tamminga, 1993), comparisons between omasal and fecal NDF flows, as well as ruminal and total NDF digestibility, can be used as indirect measures of accuracy and precision of the flow measurements. Relatively small residuals from regressions of the extent and amount of ruminal NDF digestion against the extent and amount of total-tract NDF digestion indicated only small random errors in measurements of omasal digesta flow (Huhtanen et al., 2010). Digestion of NDF

Table 4. Residual analysis of dietary N flows at the omasum

\begin{tabular}{|c|c|c|c|c|c|c|}
\hline \multirow[b]{2}{*}{ Item } & \multicolumn{3}{|c|}{ Mean bias } & \multicolumn{3}{|c|}{ Linear bias } \\
\hline & Estimate & $\mathrm{SE}$ & $P$-value & Estimate & $\mathrm{SE}$ & $P$-value \\
\hline Observed feed $\mathrm{N}$ & 11.0 & 1.74 & $<0.001$ & -0.22 & 0.026 & $<0.001$ \\
\hline MN correction $^{1}$ & -5.7 & 1.83 & $<0.001$ & -0.26 & 0.028 & $<0.001$ \\
\hline Endogenous $\mathrm{N}^{2}$ & -0.1 & 1.80 & 0.96 & -0.23 & 0.027 & $<0.001$ \\
\hline Endogenous $\mathrm{N}^{3}$ & -28.6 & 1.81 & $<0.001$ & -0.30 & 0.027 & $<0.001$ \\
\hline $\mathrm{MN}^{1}+\mathrm{EN}^{2}$ & -16.0 & 1.83 & $<0.001$ & -0.26 & 0.028 & $<0.001$ \\
\hline $\mathrm{MN}^{1}+\mathrm{EN}^{3}$ & -44.6 & 1.85 & $<0.001$ & -0.33 & 0.028 & $<0.001$ \\
\hline
\end{tabular}

${ }^{1}$ Microbial N (MN) flow underestimated by $5 \%$.

${ }^{2}$ Endogenous N (EN) flow $0.085 \mathrm{~g} / \mathrm{kg}$ of $\mathrm{BW}^{0.75}$ (Ørskov et al., 1986).

${ }^{3}$ Endogenous N flow $2.0 \mathrm{~g} / \mathrm{kg}$ of DMI (Hart and Leibholz, 1990). 


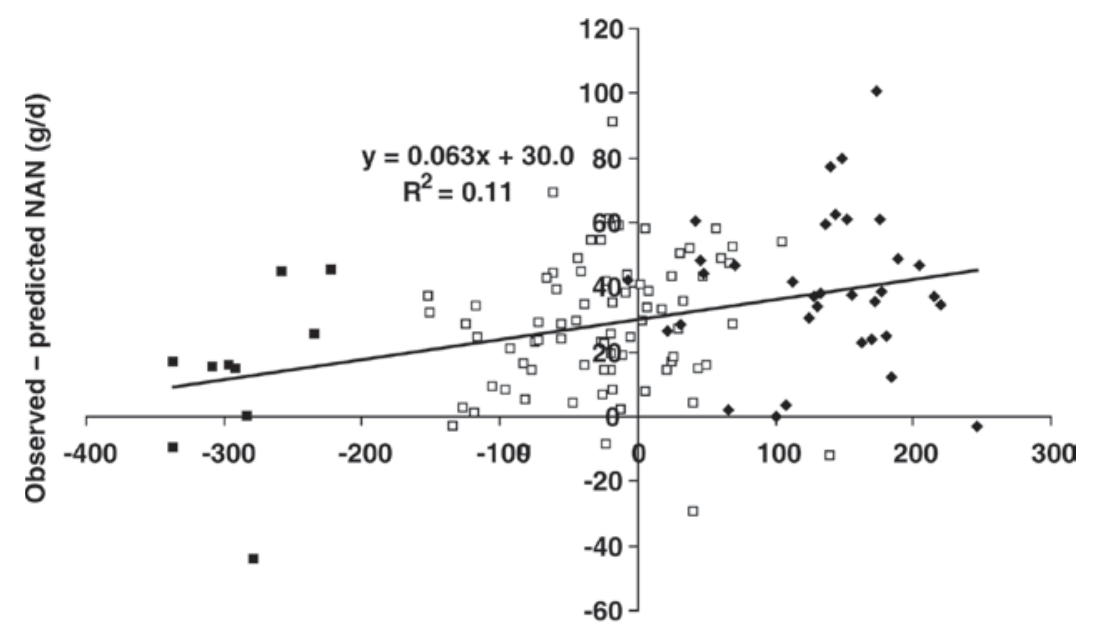

Predicted NAN flow (g/d)

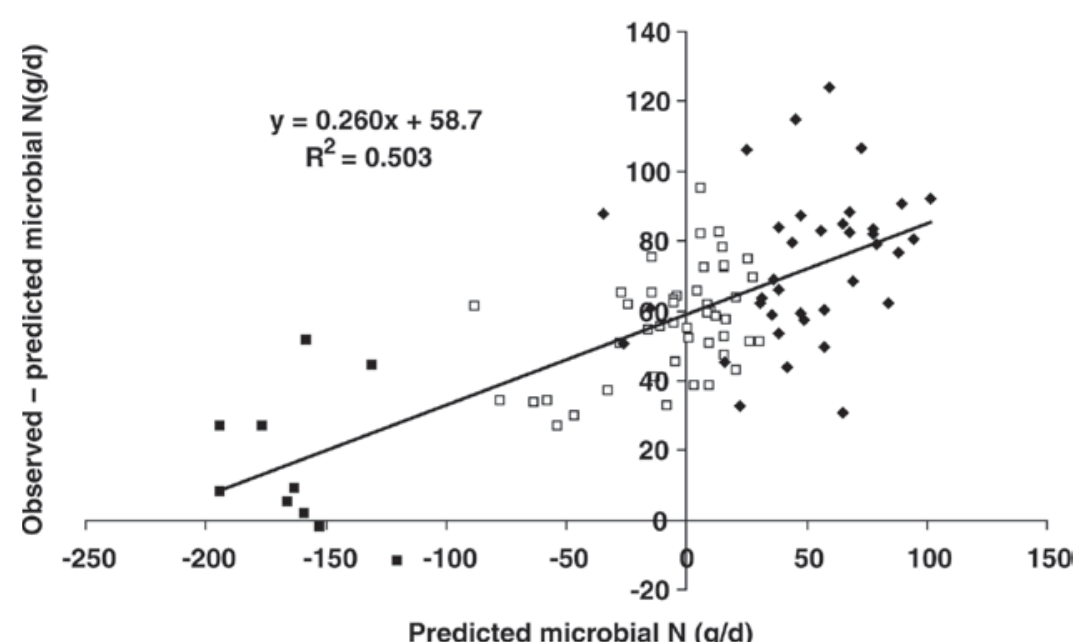

Predicted microbial $\mathbf{N}(\mathrm{g} / \mathrm{d})$

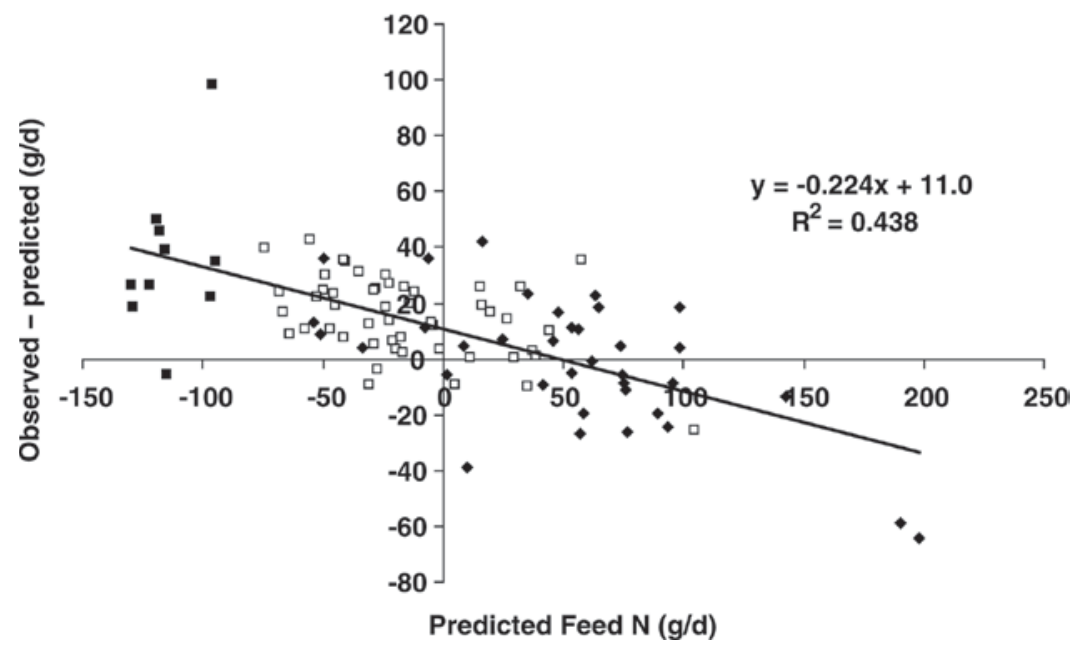

Figure 6. Plot of residuals (observed using omasal sampling - predicted using the NRC model) versus predicted estimates (NRC, 2001) for flow of NAN (top), microbial N (middle), and feed N (bottom) from the rumen. Predicted values were centered by subtracting the mean predicted value from each predicted value. European beef cattle trials; $\square$ European dairy cow trials; $\diamond$ North American dairy cow trials. 
Table 5. Regressions developed for predicting ruminal CP balance from dietary concentration of CP and RDP (g/kg of DM), ruminal degradability of dietary CP (determined using the omasal sampling technique), ruminal ammonia-N concentration, and MUN (mg/dL)

$\mathrm{X}_{1} \quad \mathrm{X}_{2} \quad$ Intercept $\mathrm{SE} \quad P$-value Slope $_{1}$

$\mathrm{Y}=$ ruminal CP balance

$(\mathrm{g} / \mathrm{kg}$ of DMI)

$\mathrm{CP}$

RDP

CP

RDP

Ammonia-N

Intercept

SE

$\mathrm{SE}$

$P$-value

$\mathrm{RMSE}^{1}$

$\mathrm{AIC}^{2}$

MUN

Degr $^{3}$
RUP

$\begin{array}{ll}-81 & 13 \\ -83 & 12\end{array}$

13

${ }^{1}$ Residual

-148
-23

$\begin{array}{rr}-89 & 12 \\ -148 & 20\end{array}$

$12<0.001$

$<0.001$
$<0.001$
$<0.001$
$<0.001$
$<0.001$

0.55

0.079

$\begin{array}{rrr}-25 & 5.7 & <0.001\end{array}$

0.78
0.76
0.59
3.2
3.0

0.099

$<0.001$

$0.098<0.001$

0.098
0.077

$<0.001$
$<0.001$

0.49

$<0.001$

$<0.001$

mean square error; adjusted for the random study effect.

${ }^{2}$ Akaike's information criteria.

${ }^{3}$ Ruminal protein degradability [(CP intake - microbial CP flow)/CP intake] determined using the omasal sampling technique.

Table 6. Mixed and simple regressions developed for predicting milk protein yield (MPY) and milk N efficiency (MNE) based on the flow of nutrients at the omasum

\begin{tabular}{|c|c|c|c|c|c|c|c|c|c|c|c|c|c|c|c|}
\hline $\mathrm{X}_{1}$ & $\mathrm{X}_{2}$ & $\mathrm{X}_{3}$ & Intercept & $\mathrm{SE}$ & Slope $_{1}$ & $\mathrm{SE}$ & $P$-value & Slope $_{2}$ & $\mathrm{SE}$ & $P$-value & Slope $_{3}$ & $\mathrm{SE}$ & $P$-value & $\mathrm{RMSE}^{1}$ & Adj. $R^{2}$ \\
\hline \multicolumn{16}{|l|}{$\mathrm{Y}=\mathrm{MPY}(\mathrm{g} / \mathrm{d})$} \\
\hline $\mathrm{OMI}^{2}$ & MN Eff ${ }^{3}$ & $\mathrm{RUP}^{4}$ & -281 & 75.5 & 52.7 & 3.09 & $<0.001$ & 5.51 & 2.45 & 0.03 & 2.10 & 0.50 & $<0.001$ & $34.5^{5}$ & \\
\hline OMI & MN Eff & RUP & -270 & 55.5 & 52.7 & 2.43 & $<0.001$ & 6.49 & 2.05 & 0.002 & 1.40 & 0.57 & 0.02 & $55.9^{6}$ & 0.899 \\
\hline \multicolumn{16}{|l|}{$\mathrm{Y}=\mathrm{MNE}^{7}(\mathrm{~g} / \mathrm{kg})$} \\
\hline $\mathrm{CP}^{8}$ & MN Eff & $\operatorname{Degr}^{9}$ & 537 & 30.6 & -1.46 & 0.11 & $<0.001$ & 1.97 & 0.77 & 0.01 & -83 & 30.0 & 0.01 & $9.6^{5}$ & \\
\hline $\mathrm{CP}$ & MN Eff & Degr & 517 & 24.2 & -1.54 & 0.10 & $<0.001$ & 2.47 & 0.62 & $<0.001$ & -52 & 31.9 & 0.11 & $17.8^{6}$ & 0.760 \\
\hline
\end{tabular}

${ }^{1}$ Residual mean square error.

${ }^{2} \mathrm{OM}$ intake $(\mathrm{kg} / \mathrm{d})$

${ }^{3}$ Efficiency of microbial $\mathrm{N}$ synthesis ( $\mathrm{g} / \mathrm{kg}$ of OM truly digested in the rumen) determined using the omasal sampling technique.

${ }^{4}$ RUP concentration $[(\mathrm{g} / \mathrm{d}$ CP intake - g/d microbial CP flow $) /(\mathrm{kg} / \mathrm{d}$ DMI $)]$ determined using the omasal sampling technique.

${ }^{5}$ Mixed regression model; adjusted for random study effect.

${ }^{6}$ Fixed (simple) regression model.

${ }^{7}$ Milk N (g)/CP intake $(\mathrm{kg})$

${ }^{8}$ Dietary $\mathrm{CP}$ concentration.

${ }^{9}$ Ruminal protein degradability [(CP intake - microbial $\mathrm{CP}$ flow $) / \mathrm{CP}$ intake] determined using the omasal sampling technique. 
is discussed in more detail in the companion paper (Huhtanen et al., 2010).

Our analyses showed that microbial $\mathrm{N}$ flows measured with the omasal sampling technique were linearly correlated with nutrient supply, regardless of whether expressed per unit of DM or OM intake, or in units related more directly to fermentable energy supply, such as OMTDR or TDN intake (Table 2). Akaike's information criterion indicated that the model based on OM intake was a slightly better predictor of microbial $\mathrm{N}$ flow than that based on OMTDR intake; this may reflect the imprecision in estimating OMTDR that results from subtracting microbial OM from total OM flow. Generally, adding other factors to these models made only minor improvements in the relationships, except for dietary $\mathrm{CP}$ concentration. Dietary $\mathrm{CP}$ content would be expected to directly influence microbial protein formation in the rumen by altering RDP supply. There were trends for efficiency of microbial $\mathrm{N}$ synthesis ( $\mathrm{g}$ of microbial $\mathrm{N} / \mathrm{kg}$ of OMTDR) to be related to both $\mathrm{CP}$ and $\mathrm{RDP}$ content of the diet (Table 2). Microbial efficiency was significantly influenced by DM intake (Figure 2). Increasing intake would increase ruminal passage rate and reduce microbial retention time and, thus, increase microbial cell yield per unit energy fermentation by diluting maintenance expenditure (Russell et al., 1992). Oba and Allen (2000) reported that feeding brown midrib corn silage to replace conventional corn silage increased DM intake, ruminal passage rates of NDF, indigestible NDF, and starch, and efficiency of microbial growth in the rumen.

The slope of the linear, mixed model regression of omasal microbial $\mathrm{N}$ flow on OMTDR intake was $26.7 \mathrm{~g}$ of N/kg. Clark et al. (1992) found a linear slope of 25.1 $\mathrm{g} / \mathrm{kg}$ of OMTDR in their analysis of literature data (obtained largely using duodenal sampling) in dairy cows fed 146 different diets. Data summarized in the NRC (2001) suggested that microbial efficiency was $29.7 \mathrm{~g}$ of N $/ \mathrm{kg}$ of OMTDR when apparent ruminal N-balance was at zero. Clark et al. (1992) also reported a quadratic relationship between OMTDR intake and microbial $\mathrm{N}$ flow, which implied that microbial flow would be maximal at $11.7 \mathrm{~kg} / \mathrm{d}$ of OMTDR and would actually decline at greater intakes of fermentable energy. We observed only a weak trend $(P=0.11)$ for a quadratic effect of OMTDR intake on microbial N flow. Furthermore, mean OMTDR intake from our more recent data set was $13.2 \mathrm{~kg} / \mathrm{d}$, which was $1.5 \mathrm{~kg} / \mathrm{d}$ greater than the apparent maximum derived in the analyses of the older data by Clark et al. (1992). Oldick et al. (1999) observed quadratic relationships of microbial protein flow to intake of $\mathrm{DM}$ and $\mathrm{NE}_{\mathrm{L}}$ in their analysis of literature data. However, the negative quadratic term reported by Oldick et al. (1999) also implied reduced microbial efficiency at greater energy intakes.

Precision in terms of $\mathrm{R}^{2}$ of the simple model regression of microbial $\mathrm{N}$ flow on $\mathrm{OM}$ intake was markedly better (0.86 vs. 0.62$)$ than the earlier model based on duodenal data (Clark et al., 1992). When OMTDR was used as independent variable, $\mathrm{R}^{2}$ values of linear and quadratic models decreased to 0.39 and 0.49 , respectively (Clark et al., 1992), whereas in the present study $\mathrm{R}^{2}$ was the same $(0.86)$ for the linear and quadratic OMTDR models as for OM intake. Clark et al. (1992) proposed that the higher correlation of microbial $\mathrm{N}$ flow with OM intake compared with OMTDR was related to factors other than the amount of OM fermented in the rumen contributing to microbial N synthesis. Another, perhaps more likely, explanation is inaccurate measurements of digesta flow. Firkins et al. (2007) used sensitivity analysis to demonstrate that underestimation of digesta $\mathrm{C}_{\mathrm{r}} \mathrm{O}_{3}$ concentration will overestimate $\mathrm{OM}$ and microbial $\mathrm{N}$ flows, and underestimate the amount of OMTDR. In contrast, overestimation of digesta $\mathrm{C}_{\mathrm{r}} \mathrm{O}_{3}$ concentration resulted in underestimated $\mathrm{OM}$ and microbial $\mathrm{N}$ flow and overestimated OMTDR. This would force an inverse relationship between OMTDR and microbial N flow. Residual standard deviations, expressed as the coefficient of variation of quadratic OMTDR models, were 11.0 and $28.6 \%$ when random trial effects were, respectively, included or excluded from the model; these values were greater than those found in the present study (6.1 vs. $12.7 \%$, respectively). In the present study, efficiency of microbial $\mathrm{N}$ synthesis increased with increased DMI, an effect that would be expected with the increased passage rates and reduced energetic maintenance costs of ruminal microbial population at higher DM intake. For example, microbial N flow more than doubled and efficiency of the synthesis increased significantly when the DM intake in dairy cows fed similar grass silage based diets was doubled and efficiency of microbial $\mathrm{N}$ synthesis was positively correlated with both liquid and particle passage rates (Volden, 1999). In the present study, dietary factors other than intake or OMTDR supply had only minimal effects on microbial $\mathrm{N}$ flow or efficiency of synthesis. This suggested that large variation in published data resulted at least partly from variable experimental methods and errors in flow estimates as highlighted by Firkins et al. (2007).

When comparing predictions of NAN flow made using the NRC (2001) model (which was developed mainly with duodenal flow data) to NAN flows measured by omasal sampling, precision (simple model regression) assessed in terms of $\mathrm{R}^{2}$ (0.91 vs. 0.64) and root mean squared prediction error (44 vs. 78 ) was somewhat 
better for the current data than for the NRC (2001) model. However, part of this apparently improved precision likely derives from our data set being more homogeneous than the NRC data set.

\section{Quantitative Comparison of Errors}

Regression of omasal NAN flow on N intake suggested that, on average, $68 \%$ of feed protein was degraded in the rumen. The mixed model from regressing NAN flow observed at the omasal canal (uncorrected for endogenous $\mathrm{N}$ ) on total protein flow from the rumen predicted by the NRC (2001) model had an $\mathrm{R}^{2}=0.97$, a slope of 1.06 (which was different from 1.0; $P=0.01$ ), and an RMSE of only 21.6 (Figure 3 ). This close agreement was surprising because the NRC (2001) model was developed from a much wider range of published results obtained using RUP estimated from in situ analyses and microbial protein flow determined using duodenal sampling. However, estimates of RDP and RUP supply made by the different approaches were very dissimilar: regression of omasal flows of microbial $\mathrm{N}$ and feed $\mathrm{N}$ on NRC predictions of microbial $\mathrm{N}$ and feed $\mathrm{N}$ yielded slopes of 1.26 (Figure 4) and 0.78 (Figure 5), respectively. Both slopes were different $(P<0.001)$ from 1.0. This indicated that, relative to estimates made using omasal sampling, the NRC (2001) model predicted lower microbial protein synthesis and greater RUP supply.

We speculate that RUP predictions in the NRC (2001) model may be inaccurate because of errors inherent to the in situ methodology. In the in situ analysis, soluble protein fraction A is assumed to be completely degraded. However, Hedqvist and Uden (2006) estimated ruminal escapes ranging from 21 to $54 \%$ for soluble proteins (which usually represented small proportions of total CP) extracted from several feedstuffs when applying a liquid passage rate of $0.16 / \mathrm{h}$. In the present analysis of omasal sampling data, an estimated 7 to $9 \%$ of protein predicted to be ruminally degraded by the NRC (2001) model appeared to escape the rumen as undegraded protein. Appearance of RDP as RUP is also consistent with both in vitro (Peltekova and Broderick, 1996; Hedqvist and Uden, 2006) and in vivo studies (Hristov and Broderick, 1996; Choi et al., 2002; Reynal et al., 2007) demonstrating the escape of soluble NAN (free AA, peptides and soluble proteins) in the liquid phase. Of course, this type of error would, in fact, result in an underestimation of protein escape, and further regression analysis indicated that RUP estimated with the NRC (2001) model was actually $26 \%$ greater than that measured by omasal sampling. These observations confirm the inadequacy of simple kinetic models used to estimate ruminal protein degradability from in situ data. Most feed protein evaluation models assume that the rumen behaves as a single compartment system with random passage of feed particles. In a recent meta-analysis (Huhtanen and Hristov, 2009), the mean passage rate of forages (998 diets) averaged 0.05/h (SD $=0.002)$ when calculated using NRC (2001) equations. The corresponding ruminal residence time $(20 \mathrm{~h})$ is markedly shorter than that estimated from duodenal marker excretion curves (Huhtanen and Hristov, 2001; Lund et al., 2006), or from indigestible NDF passage rates estimated using the rumen evacuation technique (Huhtanen et al., 2006). Potential errors may also arise due to nylon bags physically restricting test proteins from microbial degradation and underestimation of microbial $\mathrm{N}$ contamination in undigested feed residues (Broderick and Cochran, 2000). Reported in situ degradation rates often are too low to yield ruminal escapes that correspond to observed protein utilization in lactating cows in vivo. Furthermore, Huhtanen et al. (2008) and Rinne et al. (2009) both reported that application of assumed constant ruminal degradation coefficients for forage protein resulted in more accurate predictions of ruminal NAN flow compared with applying ruminal protein degradabilities determined using the in situ technique.

It is difficult to explain why the NRC (2001) model would predict microbial $\mathrm{N}$ flows from the rumen that are lower than those measured by omasal sampling. However, it should be noted that the database used to develop the current NRC model was derived from results published mainly between 1985 and 1997. Feed intakes and presumably microbial $\mathrm{N}$ formation may be expected to have increased at the greater intakes reported in more recent studies. Errors inherent in the omasal sampling method may have contributed to this divergence. However, estimates of microbial protein synthesis using the omasal sampling technique may be more accurate because of the application of a triple-marker technique (France and Siddons, 1986; Ahvenjärvi et al., 2003; Huhtanen et al., 2010), rather than due to any greater errors attributable simply to the sampling of digesta at the abomasum or duodenum. Additionally, 75 out of 96 observations of microbial CP flow in the omasal database were determined using ${ }^{15} \mathrm{~N}$, rather than purines, as the microbial marker. Purine bases appear to be less accurate as a microbial marker than ${ }^{15} \mathrm{~N}$ (Reynal et al., 2005). Improved accuracy in quantifying microbial CP flow will, of course, also improve the accuracy of RUP predictions.

Ruminal N-balance was most closely related to ammonia-N concentration. Model solutions indicated that zero ruminal N-balance (where omasal $\mathrm{N}$ outflow equaled $\mathrm{N}$ intake) would occur when diets averaged 147 $\mathrm{g}$ of $\mathrm{CP}$ and $106 \mathrm{~g}$ of $\mathrm{RDP} / \mathrm{kg}$ of $\mathrm{DM}$ and a mean 
ruminal ammonia-N concentration of $7.1 \mathrm{mg} / \mathrm{dL}$. This ammonia- $\mathrm{N}$ concentration is somewhat greater than the $5.0 \mathrm{mg} / \mathrm{dL}$ reported by Satter and Slyter (1974) as the ruminal level above which ammonia gives no further increase in microbial protein formation. Presumably, diets containing less $\mathrm{CP}$ and $\mathrm{RDP}$ will give rise to net capture of recycled $\mathrm{N}$. Recycling of urea $\mathrm{N}$ into the rumen, via saliva or directly across the gut wall, would divert $\mathrm{N}$ from urinary excretion (Lobley et al., 2000) and may prove a useful approach for reducing $\mathrm{N}$ losses to the environment from dairy production.

Metabolizable protein supply is the main factor that determines milk protein secretion in lactating dairy cows (NRC, 2001); thus, variation in omasal NAN supply due to differences in RUP or microbial N flow would be expected to be reflected in differences in MPY. Milk protein yield was positively related to OM intake plus the efficiency of microbial N synthesis and RUP supply, measured using the omasal sampling technique (Table $5)$. The mixed model explained about $90 \%$ of the observed variation in MPY. Moreover, apparent MNE (milk $\mathrm{N} / \mathrm{N}$ intake) was inversely related to dietary $\mathrm{CP}$ content and measured dietary protein degradability and positively associated with measured efficiency of microbial N synthesis (Table 5). Similar relationships of MPY and MNE to dietary CP content, intake, and ruminal metabolism, as estimated using the NRC (2001) model, were also obtained in a meta-analysis of results from trials evaluating more than 1,700 diets in lactating cows (Huhtanen and Hristov, 2009).

Sampling through ruminal cannulas from the reticulum, the region of the reticular-rumen from which digesta pass into the omasum, has been tested in at least 2 studies. Using triple-marker techniques at both sites, Hristov (2007) obtained similar estimates of total NAN flow using reticular and duodenal sampling in lactating dairy cows; however, there were trends for reticular sampling to yield slightly lower estimates of microbial NAN flow and higher estimates of NAN flow from feed origin. Krizsan et al. (2010) compared reticular to omasal sampling, also when applying triple-marker procedures in lactating cows; this group found no differences $(P \geq$ 0.71 ) in estimates of flows of microbial NAN, feed NAN, and total NAN between sampling sites. These findings indicate that successful quantitation of N-metabolism in the rumen may be possible without having to employ elaborate equipment for collecting digesta directly from the omasal canal.

\section{CONCLUSIONS}

Mixed model analysis of a large data set (32 studies from North America and Northern Europe in which 122 diets were fed) evaluated the precision and accuracy of the omasal sampling technique for quantifying ruminal $\mathrm{N}$-metabolism. Linear regressions developed from these data were used to predict microbial $\mathrm{N}$ flows to the omasum from intakes of DM, OM, and TDN. Efficiency of microbial $\mathrm{N}$ synthesis increased with intake, and the estimated RDP content of feed CP averaged $68 \%$. Regressions of observed omasal flow of RUP and RDP on flows predicted by the NRC model indicated that NRC predictions of RUP were $22 \%$ greater, and predictions of microbial CP flow were $26 \%$ lower, than those measured using omasal sampling. Zero N-balance in the rumen, the point where omasal $\mathrm{CP}$ flow equaled $\mathrm{CP}$ intake, was estimated to occur at mean dietary concentrations of $14.7 \% \mathrm{CP}$ and $10.6 \% \mathrm{RDP}$, where ruminal ammonia-N and MUN were 7.1 and $8.3 \mathrm{mg} / 100 \mathrm{~mL}$, respectively. Regression models yielded reliable predictions of MPY from measured microbial CP and RUP flows. Overall, these findings provide evidence that the omasal sampling technique yields useful estimates of ruminal microbial protein synthesis and RDP and RUP supply in high-producing cattle.

\section{ACKNOWLEDGMENTS}

The important experimental and intellectual contributions of the late Santiago M. Reynal to this modelling effort are gratefully acknowledged by the other authors. He was directly or indirectly involved in all of the omasal sampling trials that formed the North American portion of the database. Experiments within the European portion of the database were supported by funding received from the European Union [Project QLK1-2002-02362; Production of CLA-enriched products by natural means; and LIPGENE, an EU Sixth Integrated Project (2004-2009; http://www.lipgene. tcd.ie)], and the Finnish Ministry of Agriculture and Forestry.

\section{REFERENCES}

Ahvenjärvi, S., A. Vanhatalo, and P. Huhtanen. 2002. Supplementing barley or rapeseed meal to dairy cows fed grass-red clover silage: I. Rumen degradability and microbial flow. J. Anim. Sci. 80:21762187.

Ahvenjärvi, S., A. Vanhatalo, P. Huhtanen, and T. Varvikko. 2000. Determination of forestomach digestion in lactating dairy cows by omasal or duodenal sampling. Br. J. Nutr. 83:67-77.

Ahvenjärvi, S., A. Vanhatalo, K. J. Shingfield, and P. Huhtanen. 2003. Determination of digesta flow entering the omasal canal of dairy cows using different marker systems. Br. J. Nutr. 90:41-52.

Broderick, G. A., and M. K. Clayton. 1997. A statistical evaluation of animal and nutritional factors influencing concentrations of milk urea nitrogen. J. Dairy Sci. 80:2964-2971.

Broderick, G. A., and R. C. Cochran. 2000. In vitro and in situ methods for estimating digestibility. Pages 53-85 in Feeding Systems and Feed Evaluation Models. M. K. Theodorou and J. France, ed. CABI Publishing, CAB International, Wallingford, UK.

Choi, C. W., S. Ahvenjärvi, A. Vanhatalo, V. Toivonen, and P. Huhtanen. 2002. Quantitation of the flow of soluble non-ammonia 
nitrogen entering the omasal canal of dairy cows fed grass silage based diets. Anim. Feed Sci. Technol. 96:203-220.

Clark, J. H., T. H. Klusmeyer, and M. R. Cameron. 1992. Symposium: Nitrogen metabolism and amino acid nutrition in dairy cattle: Microbial protein synthesis and flows of nitrogen fractions to the duodenum of dairy cows. J. Dairy Sci. 75:2304-2323.

Firkins, J. L., Z. Yu, and M. Morrison. 2007. Ruminal nitrogen metabolism: Perspectives for integration of microbiology and nutrition for dairy. J. Dairy Sci. 90(E. Suppl.):E1-E16.

France, J., and R. C. Siddons. 1986. Determination of digesta flow by continuous marker infusion. J. Theor. Biol. 121:105-119.

Harmon, D. L., and C. J. Richards. 1997. Considerations for gastrointestinal cannulation in ruminants. J. Anim. Sci. 75:22482255.

Hart, F. J., and J. Leibholz. 1990. A note on the flow of endogenous protein to the omasum and abomasum of steers. Anim. Prod. $51: 217-219$.

Hedqvist, H., and P. Uden. 2006. Measurement of soluble protein degradation in the rumen. Anim. Feed Sci. Technol. 126:1-21.

Hristov, A. N. 2007. Comparative characterization of reticular and duodenal digesta and possibilities of estimating microbial outflow from the rumen based on reticular sampling in dairy cows. J. Anim. Sci. 85:2606-2613.

Hristov, A. N., and G. A. Broderick. 1996. Synthesis of microbial protein in ruminally cannulated cows fed alfalfa silage, alfalfa hay or corn silage. J. Dairy Sci. 79:1627-1637.

Huhtanen, P., S. Ahvenjärvi, G. A. Broderick, S. M. Reynal, and K. J. Shingfield. 2010. Quantifying ruminal digestion of organic matter and neutral detergent fiber using omasal sampling in cattle-A meta-analysis. J. Dairy Sci. 93:3203-3215.

Huhtanen, P., P. G. Brotz, and L. D. Satter. 1997. Omasal sampling technique for assessing fermentative digestion in the forestomach of dairy cows. J. Anim. Sci. 75:1380-1392.

Huhtanen, P., and A. N. Hristov. 2001. Estimating passage kinetics using fibre-bound ${ }^{15} \mathrm{~N}$ as an internal marker. Anim. Feed Sci. Technol. 94:29-41.

Huhtanen, P., and A. N. Hristov. 2009. A meta-analysis of the effects of dietary protein concentration and degradability on milk protein yield and milk N efficiency in dairy cows. J. Dairy Sci. 92:32223232.

Huhtanen, P., J. Nousiainen, and M. Rinne. 2006. Recent developments in forage evaluation with special reference to practical applications. Agric. Food Sci. 3:293-323.

Huhtanen, P., J. I. Nousiainen, M. Rinne, K. Kytölä, and H. Khalili. 2008. Utilization and partitioning of dietary nitrogen in dairy cows fed grass silage based diets. J. Dairy Sci. 91:3589-3599.

Ipharraguerre, I. R., S. M. Reynal, M. Lineiro, G. A. Broderick, and J. H. Clark. 2007. A comparison of sampling sites, digesta and microbial markers, and microbial references for assessing the postruminal supply of nutrients in dairy cows. J. Dairy Sci. 90:1904-1919.

Krizsan, S. J., S. Ahvenjärvi, H. Volden, and G. A. Broderick. 2010. Estimation of nutrient flows in dairy cows fed grass silage based diets at two levels of concentrate supplementation by reticular sampling as an alternative to sampling from the omasal canal. J. Dairy Sci. 93. In press.

Littell, R. C., G. A. Milliken, W. W. Stroup, and R. D. Wolfinger. 1996. SAS System for Mixed Models. SAS Institute Inc., Cary, NC.

Lobley, G. E., D. M. Bremner, and G. Zuur. 2000. Effects of diet quality on urea fates in sheep as assessed by refined, non-invasive $\left[{ }^{15} \mathrm{~N}^{15} \mathrm{~N}\right]$ urea kinetics. Br. J. Nutr. 84:459-468.
Lund, P., M. R. Weisbjerg, and T. Hvelplund. 2006. Passage kinetics of fibre in dairy cows obtained from duodenal and faecal ytterbium excretion-Effect of forage type. Anim. Feed Sci. Technol. 128:229 252.

McCullough, H. 1967. The determination of ammonia in whole blood by a direct calorimetric method. Clin. Chim. Acta 17:297-304.

MTT. 2006. Rehutaulukot ja ruokintasuositukset (Feed tables and feeding recommendations, in Finnish). http://www.mtt.fi/ rehutaulukot. Accessed Feb. 1, 2008.

NRC. 2001. Nutrient Requirements of Dairy Cattle. 7th rev. ed. National Academy Press, Washington, DC.

Oba, M., and M. S. Allen. 2000. Effects of brown midrib 3 mutation in corn silage on productivity of dairy cows fed two concentrations of dietary neutral detergent fiber: 3. Digestibility and microbial efficiency. J. Dairy Sci. 83:1350-1358.

Oldick, B. S., J. L. Firkins, and N. R. St-Pierre. 1999. Estimation of microbial nitrogen flow to the duodenum of cattle based on dry matter intake and diet composition. J. Dairy Sci. 82:1497-1511.

Ørskov, E. R., N. A. Macleod, and D. J. Kyle. 1986. Flow of nitrogen from the rumen and abomasum in cattle and sheep given protein free nutrients by intragastric infusion. Br. J. Nutr. 56:241-248.

Peltekova, V. D., and G. A. Broderick. 1996. In vitro ruminal degradation and synthesis of protein on fractions extracted from alfalfa hay and silage. J. Dairy Sci. 79:612-619.

Reynal, S. M., G. A. Broderick, and C. Bearzi. 2005. Comparison of four markers for quantifying microbial protein flow from the rumen of lactating dairy cows. J. Dairy Sci. 88:4065-4082.

Reynal, S. M., I. R. Ipharraguerre, M. Lineiro, A. F. Brito, G. A. Broderick, and J. H. Clark. 2007. Omasal flow of soluble proteins, peptides, and free amino acids in dairy cows fed diets supplemented with proteins of varying ruminal degradabilities. J. Dairy Sci. 90:1887-1903.

Rinne, M., J. Nousiainen, and P. Huhtanen. 2009. Effects of silage protein degradability and fermentation acids on metabolizable protein concentration: A meta-analysis of dairy cow production experiments. J. Dairy Sci. 92:1633-1642.

Russell, J. B., J. D. O'Connor, D. G. Fox, P. J. Van Soest, and C. J. Sniffen. 1992. A net carbohydrate and protein system for evaluating cattle diets: I. Ruminal fermentation. J. Anim. Sci. 70:3551-3561.

Satter, L. D., and L. L. Slyter. 1974. Effect of ammonia concentration on rumen microbial protein production in vitro. Br. J. Nutr. 32:199-208.

St-Pierre, N. R. 2001. Integrating quantitative findings from multiple studies using mixed model methodology. J. Dairy Sci. 84:741755.

St-Pierre, N. R. 2003. Reassessment of biases in predicted nitrogen flows to the duodenum by NRC 2001. J. Dairy Sci. 86:344-350.

Tamminga, S. 1993. Influence of feeding management on ruminant fiber digestibility. Pages 571-602 in Forage Cell Wall Structure and Digestibility. H. G. Jung, D. R. Buxton, R. D. Hatfield, and J. Ralph, ed. American Society of Agronomy, Madison, WI.

Titgemeyer, E. C. 1997. Design and interpretation of nutrient digestion studies. J. Anim. Sci. 75:2235-2247.

Volden, H. 1999. Effects of level of feeding and ruminally undegraded protein on ruminal bacterial protein synthesis, escape of dietary protein, intestinal amino acid profile, and performance of dairy cows. J. Anim. Sci. 77:1905-1918. 